\title{
KEEFEKTIFAN PBL DAN IBL DITINJAU DARI PRESTASI BELAJAR, KEMAMPUAN REPRESENTASI MATEMATIS, DAN MOTIVASI BELAJAR
}

\author{
Muhamad Farhan ${ }^{1)}$, Heri Retnawati ${ }^{2)}$ \\ Prodi Pendidikan Matematika ${ }^{1)}$, Universitas Negeri Yogyakarta ${ }^{2)}$ \\ muhamadfarhan2011@gmail.com ${ }^{1)}$, retnawati_heriuny@yahoo.co.id ${ }^{2)}$
}

\begin{abstract}
Abstrak
Penelitian ini bertujuan untuk mendeskripsikan keefektifan problem-based learning dan inquiry-based learning ditinjau dari prestasi belajar, kemampuan representasi matematis, dan motivasi belajar. Penelitian ini adalah penelitian eksperimen semu dengan pretest-posttest nonequivalent group design. Populasi dalam penelitian ini adalah seluruh siswa kelas VIII MTs sekecamatan Rasana'e Barat Kota Bima dan sampel dalam penelitian ini adalah siswa kelas VIII MTs Sartu Atap rasana'e Barat Kota Bima dan tiga kelas dipilih yaitu dua kelas eksperimen dan satu kelas kontrol. Data penelitian dianalisis dengan uji one sample t test, uji Bonferroni pada signifikansi 5\% dan uji MANOVA. Hasil penelitian menunjukkan bahwa ditinjau dari prestasi belajar, kemampuan representasi matematis, dan motivasi belajar: (1)problem-based learning dan inquiry-based learning efektif, (sedangkan pembelajaran konvensional efektif ditinjau dari motivasi belajar siswa), (2)problem-based learning dan inquiry-based learning lebih efektif dibandingkan dengan pembelajaran konvensional, dan (3) problem-based learning lebih efektif dibandingkan dengan inquiry-based learning.
\end{abstract}

Kata Kunci: problem-based learning, inquiry-based learning, prestasi belajar, kemampuan representasi matematika, motivasi belajar siswa.

\section{THE EFFECTIVENESS OF PBL AND IBL IN TERMS OF ACHIEVEMENT, MATHEMATICAL REPRESENTATION CAPABILITIES, AND MOTIVATION}

\begin{abstract}
This study aims to describe the effectiveness of problem-based learning and inquiry-based learning in terms of achievement, mathematical representation capabilities and motivation. This study was a quasi-experimental study using the pretest-posttest non-equivalent group design. The research population comprised all Year VIII students' MTs of sub-district Rasana'e Barat Kota Bima and sample was all Year VIII students of MTs Satu Atap Rasana'e Barat Kota Bima. Three classes were selected as the research sample, namely two experimental classes and one control class. The data were analyzed using one sample t test, Bonferroni t test at the significance level of 5\% and MANOVA test. The results show that in terms of achievement, mathematical representation capabilities, and motivation: (1)problem-based learning and inquiry-based learning are effective, (the conventional learning is effective in terms of students' motivation), (2)problem-based learning and inquiry-based learning are more effective than conventional learning, and (3)problem-based learning is more effective than inquiry-based learning.
\end{abstract}

Keywords: problem-based learning, inquiry-based learning, learning achievements, mathematical representation capabilities, students' motivation 


\section{PENDAHULUAN}

Perkembangan ilmu pengetahuan teknologi dan sains memberikan kemudahan untuk mengakses berbagai ilmu pengetahuan maupun informasi secara cepat, mudah dan akurat dari berbagai sumber. Pembelajaran matematika memegang peranan yang sangat penting dan esensial terhadap perkembangan ilmu pengetahuan, teknologi dan sains tersebut. Masykur Ag dan Fathani (2008, p.41) mengatakan bahwa matematika merupakan subjek yang sangat penting dalam sistem pendidikan. Negara yang mengabaikan pendidikan matematika sebagai prioritas utama akan tertinggal dari kemajuan segala bidang (terutama sains dan teknologi).

Permen Nomor 22 Tahun 2006 tentang standar isi untuk satuan pendidikan dasar dan menengah menjelaskan bahwa mata pelajaran matematika bertujuan agar peserta didik memiliki kemampuan sebagai berikut: (1) memahami konsep matematika, menjelaskan keterkaitan antarkonsep dan mengaplikasikan konsep atau algoritma secara luwes, akurat, efisien, dan tepat dalam pemecahan masalah, (2) menggunakan penalaran pada pola dan sifat, melakukan manipulasi matematika dalam membuat generalisasi, menyusun bukti, atau menjelaskan gagasan dan pernyataan matematika, (3) memecahkan masalah yang meliputi kemampuan memahami masalah, merancang model matematika, menyelesaikan model dan menafsirkan solusi yang diperoleh, (4) mengomunikasikan gagasan dengan simbol, tabel, diagram, atau media lain untuk memperjelas keadaan atau masalah, dan (5) memiliki sikap menghargai kegunaan matematika dalam kehidupan, yaitu memiliki rasa ingin tahu, perhatian, dan minat dalam mempelajari matematika, serta sikap ulet dan percaya diri dalam pemecahan masalah.

Hal senada juga sebagaimana yang dirumuskan oleh NCTM (2000, p.7) berkaitan dengan proses pembelajaran yang lebih menekankan pada lima standar proses yaitu pemecahan masalah (problem solving), penalaran dan bukti (reason and proof), komunikasi (communication), koneksi (connections), dan representasi (representation).

Proses pembelajaran yang melibatkan siswa secara penuh dan aktif (student-centered) akan membantu siswa dalam membangun dan mengkonstruk ide-ide matematis secara mandiri. Pembelajaran yang aktif yang mencakup pada siswa aktif bertanya, berdiskusi, mengungkapkan pendapat, memberikan saran, memecahkan masalah dan lain sebagainya akan lebih memberikan kompetensi, pengetahuan dan serangkaian kecakapan yang siswa butuhkan dari waktu ke waktu serta meningkatkan kemampuan literasi matematis siswa, kemampuan memecahkan masalah mulai dari kemampuan mengidentifikasi, menganalisis, membuat hipotesis, menyimpulkan bahkan siswa mampu mengembangkan masalah yang diberikan. Adapun Pembelajaran yang berpusat pada guru (teacher-centered) menjadikan siswa pasif dalam pembelajaran, siswa hanya menerima pengetahuan yang disampaikan oleh guru dan siswa tidak diberikan kesempatan untuk mengkonstruk matematika berdasarkan ide-ide siswa.

White \& Harbaugh (2010, p.71) mengatakan bahwa pembelajaran tradisional (pembelajaran konvensional) pada dasarnya mampu mengontrol lingkungan kelas secara penuh, akan tetapi tidak efektif dalam membangun pemahaman siswa, siswa akan pasif dan tidak diberikan kesempatan untuk mengkonstruk ide-ide matematis, pembelajaran yang berlangsung tidak menyenangkan bagi siswa dan tidak mampu membangkitkan hasrat atau keinginan siswa untuk belajar. Dengan demikian, pembelajaran matematika yang diharapkan adalah pembelajaran yang melibatkan siswa secara aktif sehingga siswa mampu menguasai konsep matematis.

Harian Kompas 2 juni 2012 menyebutkan bahwa siswa yang tidak lulus Ujian Nasional terbanyak pada mata pelajaran matematika dan disebutkan juga menteri pendidikan dan kebudayaan Mohammad Nuh menyatakan bahwa sebanyak 229 siswa atau $1,44 \%$ siswa tidak lulus mata pelajaran matematika pada ujian nasional tahun 2012 tingkat SMP dan sederajat, secara keseluruhan sebanyak 15.945 siswa yang tidak lulus Ujian Nasional dari 3.697.865 siswa peserta Ujian Nasional (http://edukasi.kompas.com).

Data dari PISA sebagaimana yang disebutkan oleh Wardhani \& Rumiati (2011, p.1) bahwa Data PISA (Programme for International Student Assessment) tahun 2000, 2003, 2006, 2009 menunjukkan hasil yang tidak banyak berubah pada setiap keikutsertaan. Rata-rata skor prestasi literasi matematika pada PISA tahun 2009, Indonesia hanya menduduki rangking 61 dari 65 peserta dengan rata-rata skor 371 , sementara rata-rata skor internasional adalah 496. Hasil PISA ini akan menunjukkan dan menilai sejauh mana siswa yang duduk di akhir tahun pendidikan dasar sudah menguasai pengetahuan 
dan keterampilan yang penting untuk dapat berpartisipasi di masyarakat.

Pentingnya kemampuan representasi matematika secara jelas disampaikan dalam Peraturan Pemerintah nomor 22 Tahun 2006 tentang standar. Salah satu tujuan pembelajaran matematika adalah agar siswa mampu: (3) memecahkan masalah yang meliputi kemampuan memahami masalah, merancang model matematika, menyelesaikan model dan menafsirkan solusi yang diperoleh, (4) mengomunikasikan gagasan dengan simbol, tabel, diagram, atau media lain untuk memperjelas keadaan atau masalah. Konstruksi representasi matematis yang tepat akan memudahkan siswa dalam melakukan pemecahan masalah. Suatu masalah yang rumit akan menjadi lebih sederhana jika menggunakan representasi yang sesuai dengan permasalahan tersebut. bilamana siswa memiliki akses ke representasi-representasi dan gagasan-gagasan yang mereka tampilkan, mereka memiliki sekumpulan alat yang siap secara signifikan akan memperluas kapasitas mereka dalam berpikir matematis (NCTM, 2000, p.67).

Kemampuan representasi memberikan peranan yang sangat penting dalam pembelajaran matematika. Keller \& Hirsch (Venkat \& Essien, 2011, p.150) menyatakan bahwa penggunaan representasi dalam pembelajaran matematika memungkinkan siswa untuk mengkonkritkan beberapa konsep yang dapat digunakan untuk mengurangi kesulitan belajar sehingga matematika menjadi lebih interaktif dan menarik yang memfasilitasi siswa untuk menghubungkan kognitif pada representasi. Beetlestone (2012, p.3) mengatakan bahwa representasi merupakan kreatifitas yang melibatkan pengungkapan atau pengeksperisian gagasan dan perasaan serta penggunaan berbagai macam cara untuk melakukannya.

Lesh, Post dan Behr (Hwang, et al, 2007, p.192) membagi representasi yang digunakan dalam pendidikan matematika dalam lima jenis, meliputi representasi objek dunia nyata, representsi konkret, representasi simbol aritmetika, representasi bahasa lisan atau verbal dan representasi gambar atau grafik. Lebih lanjut dikatakan Johnson, et al (Hwang, et al, 2007, pp.192193) tiga diantaranya lebih abstrak dan merupakan level tertinggi dalam representasi pada pemecahan masalah matematika yaitu: (1) keterampilan representasi bahasa lisan atau verbal yakni keterampilan untuk menerjemahkan sesuatu yang diamati ke dalam masalah matematika dengan menggunakan representasi lisan atau verbal, (2) keterampilan representasi gambar atau grafik yakni keterampilan menerjemahkan masalah matematika ke dalam bentuk representasi gambar atau grafik, (3) keterampilan simbol aritmatika yakni keterampilan menerjemahkan masalah matematika ke dalam representasi formula (rumus) aritmatik.

Motivasi belajar dalam proses pembelajaran matematika sangat diperlukan dan guru harus senantiasa memberikan motivasi-motivasi dalam setiap proses pembelajaran karena itu akan sangat berguna dalam keberhasilan proses pembelajaran yang akan dilakukan. Mudjiman (2007, p.43) mengatakan bahwa kegiatan pembelajaran akan selalu didahului oleh proses pembuatan keputusan-keputusan untuk berbuat atau tidak berbuat, apabila motivasinya cukup kuat maka ia akan memutuskan untuk melakukan kegiatan belajar. Sebaliknya, apabila motivasinya tidak cukup kuat maka ia akan memutuskan untuk tidak melakukan kegiatan belajar.

Sobel \& Maletsky (2004, pp.31-32) menegaskan bahwa penting untuk dicatat bahwa murid-murid seharusnya diberi waktu yang cukup untuk menformulasikan dugaan dan mendiskusikannya di dalam kelas sebelum mencoba mencari jawaban yang benar melalui perhitungan. Jika tidak disediakan waktu yang cukup, topik yang disampaikan hanya akan membuat murid-murid melakukan perhitungan dan kehilangan aspek motivasi.

Motivasi merupakan suatu stimulus yang memberikan kekuatan (energi) kepada seseorang untuk melaksanakan suatu aktivitas, yang mengarahkannnya agar tepat pada tujuan yang diharapkan dan menjaga agar tetap stabil terhadap apa yang telah dilakukan. Kecenderungan motivasi dalam diri seorang individu akan terlihat pada kinerja siswa pada aktivitas pembelajaran matematika. Santrock (2009, p.199) mengatakan bahwa motivasi melibatkan proses yang memberikan energi, mengarahkan, dan mempertahankan perilaku.

Motivasi seseorang untuk melakukan sesuatu kegiatan atau melakukan proses pembelajaran dipengaruhi oleh faktor internal dan eksternal atau lebih dikenal dengan motivasi intrinsik dan motivasi ekstrinsik. Santrock (2011, p.441) mengatakan bahwa motivasi intrinsik melibatkan motivasi internal untuk melakukan sesuatu untuk kepentingan diri sendiri (tujuan itu sendiri). Sedangkan Arends (2008, p.143) menyebutkan bahwa motivasi intrinsik menyebabkan orang bertindak dengan 
cara tertentu karena tindakan itu membawa kepuasan atau kesenangan pribadi.

Arends \& Kilcher (2010, p.57) menyatakan bahwa "extrinsic motivation is at play when individuals take action to capture a desired reward". Maksudnya bahwa motivasi ekstrinsik adalah tindakan individu melakukan tindakan untuk mendapatkan hadiah yang diinginkan. Menurut Woolfolk (2007, p.407) menyatakan bahwa "extrinsic motivation is based on factors not related to the activity it self. Student are not really interests in the activity for its own sake; we care only about it will gain us". Motivasi ekstrinsik didasarkan pada faktor-faktor yang tidak berhubungan dengan kegiatan itu sendiri, siswa tidak benar-benar peduli dalam kegiatan untuk kepentingan dirinya sendiri, siswa hanya peduli terhadap apa yang didapatkan dari kegiatan tersebut.

Menurut Bomia Motivasi belajar merujuk pada kemauan, kebutuhan, keinginan dan keharusan siswa untuk ikut berpartisipasi dan berhasil dalam proses pembelajaran. Lebih lanjut Middleton dan Spanias melihat motivasi sebagai alasan individu untuk berperilaku dalam situasi tertentu. Jadi keberhasilan siswa dalam pembelajaran matematika adalah pengaruh kuat dari motivasi untuk mencapai suatu tujuan (Yunus \& Ali, 2009, p.93). Menurut Uno (2011, p.9) motivasi intrinsik berisi: (1) penyesuaian tugas dengan minat, (2) perencanaan yang penuh variasi, (3) umpan balik atas respon siswa, (4) kesempatan respon peserta didik yang aktif, dan (5) kesempatan peserta didik untuk menyelesaikan tugasnya.

Motivasi ekstrinsik muncul disebabkan adanya keinginan untuk memperoleh penghargaan tertentu dari guru, orang tua, maupun teman sebaya baik itu berupa hadiah, nilai, hukuman maupun pujian yang dapat meningkatkan keinginan ataupun kemauan siswa dalam belajar. Menurut Uno (2011, p.9) mengatakan bahwa motivasi ekstrinsik mencakup antara lain: (1) penyesuaian tugas dengan minat, (2) perencanaan yang penuh variasi, (3) respon siswa, (4) kesempatan peserta didik yang aktif, (5) kesempatan peserta didik untuk menyelesaikan tugas pekerjaannya, dan (6) adanya kegiatan yang menarik dalam belajar.

Indikator motivasi intrinsik dan motivasi ekstrinsik dapat disimpulkan berdasarkan pendapat Uno (2011, p.10) bahwa motivasi adalah dorongan internal dan eksternal dalam diri seseorang untuk mengadakan perubahan tingkah la$\mathrm{ku}$, yang mempunyai indikator sebagai berikut:
(1) adanya hasrat dan keinginan untuk melakukan kegiatan, (2) adanya dorongan dan kebutuhan melakukan kegiatan, (3) adanya harapan dan cita-cita, (4) penghargaan dan penghormatan atas diri, (5) adanya lingkungan yang baik, dan (6) adanya kegiatan yang menarik.

Berbagai masalah yang telah dikemukakan tersebut membutuhkan suatu solusi yang dapat mengatasinya sehingga prestasi belajar, kemampuan representasi matematika dan motivasi belajar siswa dalam proses pembelajaran matematika dapat meningkat dan dapat meningkatkan mutu pendidikan. Askew \& Williams (Muijs \& Reynolds, 2008, pp.341-342) menyebutkan bahwa model yang diusulkan adalah dimana guru mulai dengan sebuah contoh atau situasi yang realistis, mengubahnya menjadi suatu model matematika, mengarahkannya ke solusi matematika yang kemudian diinterpretasikan kembali sebagai sebuah solusi yang realistik. Strategi semacam ini jelas akan berguna dalam mengkaitkan pengetahuan dan aplikasi matematika dan dunia riil. Lebih lanjut dikatakan oleh Gravemeijer (Muijs \& Reynolds, 2008, p.343) bahwa agar efektif contoh riil perlu lebih banyak dihubungkan dengan pengalaman aktual murid.

Pemahaman matematika dengan menggunakan masalah yang riil membutuhkan suatu pembelajaran yang benar-benar merancang suatu lingkungan belajar dengan permasalahan yang riil atau nyata dengan aktivitas siswa. Dalam hal ini problem-based learning (PBL) dan inquirybased learning (IBL) yang merupakan pembelajaran berbasis masalah akan mengantarkan siswa pada situasi masalah yang riil. Masalahmasalah yang riil sangat dibutuhkan dalam proses pembelajaran untuk meningkatkan kemampuan siswa dalam pembelajaran matematika yakni kemampuan siswa dalam bernalar, berpikir logis, sampai pada kemampuan siswa berpikir tingkat tinggi. Pembelajaran berbasis masalah pula akan memungkinkan siswa untuk menemukan pembelajaran yang bermakna, siswa akan terlatih untuk memecahkan masalahmasalah riil yang sering muncul serta siswa akan lebih aktif.

Duch, Groh, \& Allen (2001, p.6) mengatakan bahwa di dalam PBL, masalah yang "realworld" digunakan untuk memotivasi siswa untuk mengidentifikasi dan meneliti konsep-konsep yang perlu mereka ketahui untuk bekerja melalui masalah tersebut. Barrows dan Tamblyn (Baden \& Major, 2004, pp.3-4) menyajikan karakteristik PBL sebagai berikut: (1) masalah 
yang disajikan secara kompleks terkait dengan masalah yang riil yang tidak mempunyai satu jawaban agar proses pembelajaran lebih terfokus terhadap apa yang disampaikan, (2) siswa belajar dalam kelompok kecil untuk menghadapi, mengidentifikasi dan mengembangkan masalah, (3) siswa memperoleh informasi (pengetahuan) baru dari situasi masalah yang dihadapi melalui pembelajaran "self-directed", (4) guru bertindak sebagai fasilitator dalam proses pembelajaran, dan (5) situasi masalah yang disajikan dapat meningkatkan kemampuan pemecahan masalah. Arends (2008: 57) menyebutkan Sintaksis untuk problem-based Learning (PBL) melalui 5 fase seperti pada tabel 1 di bawah ini.

Tabel 1. Sintaksis Problem-Based Learning

\begin{tabular}{|c|c|}
\hline Fase & Perilaku guru \\
\hline $\begin{array}{l}\text { Memberikan orientasi tentang } \\
\text { permasalahannya kepada siswa. }\end{array}$ & $\begin{array}{l}\text { Guru membahas tujuan pelajaran, mendeskripsikan berbagai kebutuhan } \\
\text { logistic penting, dan memotivasi siswa untuk terlibat dalam kegiatan } \\
\text { mengatasi-masalah. }\end{array}$ \\
\hline $\begin{array}{l}\text { Mengorganisasikan siswa untuk } \\
\text { belajar. }\end{array}$ & $\begin{array}{l}\text { Guru membantu siswa untuk mendefinisikan dan mengorganisasikan tugas- } \\
\text { tugas belajar yang terkait dengan permasalahannya. }\end{array}$ \\
\hline $\begin{array}{l}\text { Membantu investigasi mandiri } \\
\text { dan kelompok. }\end{array}$ & $\begin{array}{l}\text { Guru mendorong siswa untuk mendapatkan informasi yang tepat, } \\
\text { melaksanakan eksperimen, dan mencari penjelasan dan solusi. }\end{array}$ \\
\hline $\begin{array}{l}\text { Mengembangkan } \quad \text { dan } \\
\text { mempresentasikan artefak dan } \\
\text { exhibit. }\end{array}$ & $\begin{array}{l}\text { Guru membantu siswa dalam merencanakan dan menyiapkan artefak-artefak } \\
\text { yang tepat, seperti laporan, rekaman video, dan model-model, dan membantu } \\
\text { mereka untuk menyampaikannya pada orang lain. }\end{array}$ \\
\hline $\begin{array}{l}\text { Menganalisis dan mengevaluasi } \\
\text { proses mengatasi-masalah. }\end{array}$ & $\begin{array}{l}\text { Guru membantu siswa untuk melakukan refleksi terhadap investigasinya dan } \\
\text { proses-proses yang mereka gunakan. }\end{array}$ \\
\hline
\end{tabular}

Pembelajaran inquiry-based learning (IBL) merupakan pembelajaran kontruktivisme yang melibatkan siswa secara aktif di dalam pembelajaran, memberikan kesempatan kepada siswa untuk mengumpulkan dan menganalisis informasi, mengeksplorasi pemikiran dan penalarannya sehingga siswa memperoleh pemahaman yang mendalam mengenai materi pembelajaran yang sedang dipelajari. Siswa aktif dalam mengumpulkan berbagai sumber informasi dan mengkonstruksi pengetahuan mereka sendiri melalui pengalaman.

Coffman (2009, p.1) mengatakan bahwa inquiry didefinisikan sebagai pengalaman dan eksplorasi yang melibatkan siswa dalam proses belajar sehingga mereka memperoleh pemahaman yang lebih dalam dari materi yang diajarkan. Pembelajaran inquiry menerapkan pendekatan konstruktivis sehingga siswa berinteraksi dengan konten, mengajukan pertanyaan untuk meningkatkan pemahaman dan komprehensif serta pada saat yang sama mengkonstruksi pengetahuan mereka sendiri. Victor \& Kellough (Jacobsen, Eggen \& Kauchak, 2009, p.243) bahwa inquiry merupakan sebuah proses dalam menjawab pertanyaan-pertanyaan dan memecahkan masalah-masalah berdasarkan pada pengujian logis atas fakta-fakta dan observasi-observasi.

Menampilkan masalah yang menarik dan menantang yang sesuai dengan konteks kehidupan akan menciptakan pembelajaran yang aktif.
Magnusson \& Palincsar (Arends \& Kilcher, 2010, p.269) memberikan kriteria yang sedikit berbeda untuk membimbing pemilihan masalah dalam inquiry bahwa masalah yang diajukan adalah: (1) kaya akan konseptual yang menyediakan peluang untuk melakukan penyelidikan yang bermakna (yang akan) menghasilkan pemahaman nilai yang abadi, (2) bersifat fleksibel yang berhubungan dengan isu-isu atau masalah yang sifatnya membangun, (3) relevan dengan kehidupan anak (siswa) sehingga keduanya dapat diakses dan menarik.

Jacobsen, Eggen \& Kauchak (2009, p.243) menyatakan bahwa pengajaran inquiry dimulai dengan memberi siswa masalahmasalah yang berhubungan dengan konten yang nantinya menjadi fokus untuk aktivitas-aktivitas penelitian kelas. Dalam menyelesaikan masalah, siswa menghasilkan hipotesis atau solusi alternatif untuk masalah tersebut, mengumpulkan data yang relevan dengan hipotesis yang telah dibuat, dan mengevaluasi data tersebut untuk sampai kepada kesimpulan.

Pembelajaran matematika dengan inquirybased learning menekankan pada kemampuan siswa dalam melakukan penyelidikan terhadap berbagai masalah yang sedang dihadapi. National Research Council (Taylor \& Bilbrey, 2011, p.153) menyebutkan bahwa "the activities of inquiry include observations, questioning, gathering data, and creating explanations. Maknanya aktivitas inquiry meliputi pengamatan, 
mempertanyakan, mengumpulkan data dan menciptakan penjelasan. Jacobsen, Eggen \& Kauchak (2009, p.246) menyebutkan langkahlangkah dalam pembelajaran inquiry adalah (1) mengidentifikasi masalah, (2) membentuk hipotesis, (3) mengumpulkan data, dan (4) menganalisis data dan membuat kesimpulan.

Coffman (2009, p.7) menjelaskan bahwa di dalam proses inquiry akan meliputi beberapa hal, anatara lain meliputi: (1) mengidentifikasi pertanyaan yang ditanyakan untuk menemukan kemungkinan jawaban, (2) mengidentifikasi sumber informasi yang tepat dan berkualitas untuk membantu siswa dalam menjawab pertanyaan yang diidentifikasi, (3) memanipulasi sumber informasi (data) untuk memastikan bahwa informasi yang diidentifikasi benar dan jawaban atas pertanyaan-pertanyaan spesifik itu dieksplorasi, (4) merumuskan jawaban yang ditemukan dan mengidentifikasi kembali kesesuaian jawaban dengan pertanyaan awal (evaluasi). Moore (2009, p.184) merumuskan langkah-langkah pembelajaran inquiry dalam 5-E seperti pada Tabel 2.
Berdasarkan tahapan-tahapan proses pembelajaran problem-based learning dan inquirybased learning diharapkan dapat meningkatkan presttasi belajar, kemampuan representasi matematika dan motivasi belajar siswa. Problembased learning dan inquiry-based learning akan memberikan kesempatan kepada siswa untuk mengkonstrak sendiri pengetahuan mereka sehingga siswa mampu memecahkan masalah yang dihadapi dan juga masalah-masalah diberikan merupakan masalah-masalah yang nyata sehingga akan membantu siswa dalam proses pemecahan masalah dan masalah-masalah yang nyata tersebut akan menjadikan siswa termotivasi untuk belajar serta melatih siswa untuk berpikir dan mengembangkan ide-ide yang mereka miliki dalam bentuk kerja sama dalam kelompok-kelompok kecil. Dengan demikian penelitian ini dilakukan untuk mengetahui bagaimana keefektifan problem-based learning dan inquiry-based learning terhadapa prestasi belajar, kemampuan representasi matematika dan motivasi belajar siswa.

Tabel 2. Sintaks Inquiry-Based Learning

\begin{tabular}{cl}
\hline $\begin{array}{c}\text { Langkah-langkah } \\
\text { Pembelajaran }\end{array}$ & \multicolumn{1}{c}{ Aktivitas Pembelajaran } \\
\hline $\begin{array}{l}\text { Engage (keterlibatan } \\
\text { atau mengikutsertakan) }\end{array}$ & $\begin{array}{l}\text { Siswa menemukan dan mengidentifikasi tugas instruksional. Kegiatan ini } \\
\text { memberikan rangsangan dan menstimulasi pikirannya. Pertanyaan diajukan untuk } \\
\text { menghubungkan pengalaman belajar sebelumnya dengan sekarang dan masalah } \\
\text { terdefinisi. }\end{array}$ \\
$\begin{array}{l}\text { Explore (menjelajahi } \\
\text { atau menyelidiki) }\end{array}$ & $\begin{array}{l}\text { Siswa terlibat langsung dengan fenomena dan material. Siswa mengidentifikasi dan } \\
\text { mengembangkan konsep, proses, dan keterampilan. Siswa secara aktif } \\
\text { mengeksplorasi lingkungan mereka atau memanipulasi material. }\end{array}$ \\
Explain (menjelaskan \\
atau menerangkan)
\end{tabular}$\quad \begin{aligned} & \text { Siswa terlibat dalam analisis eksplorasi. mereka menempatkan pengalaman abstrak } \\
& \text { ke dalam bentuk yang diterapkan. Siswa berkesempatan untuk mengungkapkan } \\
& \text { pemahaman konseptual atau menampilkan keterampilan baru. Pemahaman siswa } \\
& \text { diklarifikasi dan dimodifikasi melalui kegiatan reflektif. } \\
& \text { Elaborate } \\
& \text { Siswa memperluas atau mengembangkan konsep yang telah mereka pelajari, } \\
& \text { menghubungkan konsep-konsep yang berhubungan dan mengaplikasikan } \\
& \text { pemahaman mereka dalam kehidupan. } \\
& \text { Guru menentukan apakah telah mencapai pemahaman konsep dan pengetahuan yang } \\
& \text { diharapkan. Evaluasi dan penilaian dilakukan secara kontinu selama proses } \\
& \text { pembelajaran. }\end{aligned}$

\section{METODE}

\section{Jenis Penelitian}

Jenis penelitian ini adalah penelitian eksperimen semu, karena beberapa variabel tidak bisa terkontrol seperti pengontrolan secara penuh pada penelitian eksperimen murni. Ciri utama penelitian eksperimen adalah adanya variabel perlakuan yang dimanipulasi. Dalam penelitian ini tidak semua variabel dapat dikon- trol mengingat prestasi belajar, kemampuan representasi matematika dan motivasi belajar siswa matematika dapat dipengaruhi oleh banyak faktor, seperti pengaruh dari lingkungan keluarga dan lingkungan sekolah.

\section{Waktu dan Tempat Penelitian}

Penelitian ini dilaksanakan di MTs Satu Atap Rasana'e Barat Kota Bima, NTB. Penelitian dilaksanakan pada semester genap tahun pel- 
ajaran 2012/2013 dari tanggal 25 Maret sampai dengan 22 Mei 2013.

\section{Subjek Penelitian}

Populasi dalam penelitian ini adalah seluruh siswa kelas VIII MTs se-Kecamatan Rasana'e Barat Kota Bima. Di Kecamatan Rasana'e Barat Kota Bima terdapat 3 MTs yaitu MTs Muhammadiyah Kota Bima, MTs Satu Atap Rasana'e Kota Bima dan MTs Negeri 1 Kota Bima. Berdasarkan banyaknya sekolah tersebut maka populasi dalam penelitian ini mencakup seluruh siswa kelas VIII MTs seKecamatan Rasana'e Barat Kota Bima. Pengambilan sampel pada penelitian ini dilakukan dengan cara memilih secara acak satu sekolah dari tiga sekolah yang terdapat di Kecamatan Rasana'e Barat Kota Bima sehingga terpilihlah MTs Satu Atap Rasana'e Barat Kota Bima sebagai sampel yang terdiri dari tiga kelas yaitu kelas VIIIA, VIIIB dan VIIIC dengan jumlah siswa sebanyak 104 siswa. Berdasarkan ketiga kelas tersebut dipilih secara acak untuk menentukan kelas eksperimen dan kelas kontrol sehingga diperoleh kelas VIIIA sebagai kelas inquiry-based learning, kelas VIIIB sebagai kelas konvensional dan kelas VIIIC sebagai kelas problem-based learning.

\section{Prosedur}

Desain yang digunakan dalam penelitian ini adalah pretest-posttest, nonequivalent group design. Pada awal dan akhir pembelajaran, siswa ketiga kelas diberikan tes awal dan tes akhir yaitu tes prestasi belajar, kemampuan representasi matematika dan angket motivasi belajar siswa.

Instrumen tes dalam penelitian ini berupa soal pilihan ganda dan essay. Soal pilihan ganda digunakan untuk mengukur prestasi belajar siswa dan soal essay digunakan untuk mengukur kemampuan representasi matematika yang meliputi aspek atau dimensi gambar, Pengungkapan atau pengekspresian matematis dan simbol aritmatika. Pemberian tes soal pilihan ganda dan essay tersebut diberikan kepada tiga kelas pada awal dan akhir pembelajaran.

Instrumen non tes berupa angket motivasi belajar siswa dengan menggunakan skala psikologi model likert, digunakan untuk mengukur motivasi belajar matematika siswa dengan lima kategori yaitu sangat tinggi, tinggi, sedang, rendah dan sangat rendah. Angket motivasi belajar siswa ini terdiri dari 23 pernyataan positif dan 7 pernyataan negatif. Dimensi motivasi belajar yaitu motivasi intrinsik dan motivasi ekstrinsik. Motivasi intrinsik meliputi (1) Adanya hasrat atau keinginan berhasil, (2) Adanya kebutuhan dan dorongan dalam belajar, (3) Adanya harapan atau cita-cita masa depan. Sedangkan motivasi ekstrinsik meliputi (1) Adanya reward dalam belajar, (2) Adanya lingkungan belajar yang kondusif sehingga memungkinkan siswa belajar dengan baik, (3) Adanya kegiatan yang menarik dalam belajar.

\section{Teknik Analisis Data}

Data-data yang dideskripsikan dalam penelitian ini adalah data tes prestasi belajar, data tes kemampuan representasi matematika dan data angket motivasi belajar siswa. Data yang telah diperoleh dihitung nilai rata-ratanya kemudian diinterpretasi ke dalam kriteria-kriteria yang telah ditetapkan dan ditentukan persentasenya.

Data prestasi belajar yang diperoleh melalui pengukuran dengan instrumen tes yang berbentuk pilihan ganda dikonversi sehingga menjadi nilai dengan rentang antara 0 sampai dengan 100. Skor tersebut kemudian digolongkan dalam kriteria berdasarkan kriteria ketuntasan minimal (KKM) yang ditetapkan oleh sekolah untuk mata pelajaran matematika yaitu 65. Nilai KKM ini digunakan untuk menentukan persentase banyaknya siswa yang mencapai kriteria ketuntasan tersebut.

Data kemampuan representasi matematika siswa menggunakan tes berbentuk 4 soal uraian. Penilaian setiap soal berdasarkan rubrik penskoran kemampuan representasi matematika siswa yang telah ditentukan berdasarkan rubrik penskoran. Untuk menetapkan skor passing grade (Minimum Passing Level), dimana akan dijadikan skor patokan efektivitas dari kemampuan representasi matematika siswa dihitung menggunakan rumus (Sudijono, 2008, p.174) sebagai berikut:

$\mu_{0}=\bar{x}_{\text {ideal }}+0,25 \cdot S_{\text {ideal }}$

Keterangan:

$\mu_{0}=$ Skor Passing Grade

$\overline{\mathrm{x}}_{\text {ideal }}=$ rerata ideal

$=\frac{1}{2}$ (skor tertinggi + skor terendah $)$

$\mathrm{S}_{\text {ideal }}=\frac{1}{6}$ (skor tertinggi - skor terendah $)$

Skor passing grade untuk kemampuan representasi matematika siswa yang akan digunakan sebagai skor patokan efektivitas dari kemampuan representasi matematika siswa pada 
masing-masing kelompok belajar problem-based learning, inquiry-based learning dan pembelajaran konvensional adalah 26 pada skala 0 sampai 48. Sedangkan skor keefektifan untuk motivasi belajar matematika siswa adalah 95 pada skala 30 sampai 150 . Untuk setiap pernyataan, responden akan diberikan skor sesuai dengan nilai skala kategori jawaban yang diberikannya berdasarkan kategori tingkat motivasi belajar siswa yang telah disesuaikan dengan skala sikap Azwar, (2011, p.163)

Adapun penentuan kategori kemampuan representasi matematika dan motivasi belajar matematika siswa ditentukan berdasarkan Tabel 3 berikut.

Tabel 3. Kategori Kemampuan Representasi Matematika dan Motivasi Belajar Matematika Siswa

\begin{tabular}{cccc}
\hline \multicolumn{2}{c}{$\begin{array}{c}\text { Kemampuan } \\
\text { Representasi } \\
\text { Matematis }\end{array}$} & \multicolumn{2}{c}{$\begin{array}{c}\text { Motivasi Belajar } \\
\text { Matematika Siswa }\end{array}$} \\
\hline Skor & Kategori & Skor & Kategori \\
\hline$x>32$ & Tinggi (T) & $120<\mathrm{X} \leq 150$ & $\begin{array}{c}\text { Sangat } \\
\text { Tinggi }\end{array}$ \\
$16 \leq \mathrm{X} \leq 32$ & $\begin{array}{c}\text { Sedang } \\
\text { (S) }\end{array}$ & $100<\mathrm{X} \leq 120$ & Tinggi \\
$\mathrm{X}<16$ & $\begin{array}{c}\text { Rendah } \\
\text { (R) }\end{array}$ & $80<\mathrm{X} \leq 100$ & Sedang \\
& & $60<\mathrm{X} \leq 80$ & $\begin{array}{c}\text { Rendah } \\
\text { Sangat } \\
\end{array}$ \\
& & $0<\mathrm{X} \leq 60$ & Rendah \\
\hline
\end{tabular}

Selanjutnya, untuk mengetahui keefektifan dari masing-masing pembelajaran ditinjau dari masing-masing variabel yaitu prestasi belajar, kemampuan representasi matematika dan motivasi belajar siswa menggunakan uji one sample t-test. Kriteria keputusan diambil berdasarkan analisis $t_{\text {hit }}$ yang dihasilkan dibandingkan dengan $t_{\text {tab }}$ pada taraf signifikansi $5 \%$. Selanjutnya untuk mengetahui kelompok belajar mana yang lebih efektif maka digunakan uji lanjut univariat dengan kriteria Bonferroni setelah dilakukan uji MANOVA (kriteria Wilks' Lambda) dengan kriteria keputusan pada taraf signifikansi $5 \%$.

Selanjutnya, sebelum dilakukan Uji MANOVA terlebih dahulu harus dipenuhi dua asumsi multivariat yaitu asumsi kenormalan multivariat menggunakan mahalanobis dengan melihat Scatter plot antara $d_{i}^{2}$ antara setiap pengamatan dengan vektor rata-rata setelah diurutkan, dengan $\chi_{p}^{2}\left(\frac{n-i+1 / 2}{n}\right)$ dan asumsi homogenitas multivariat dengan melihat Box'M dengan bantuan program SPSS 16 for windows.

\section{HASIL DAN PEMBAHASAN}

\section{Hasil Penelitian}

Data yang diperoleh dalam penelitian ini adalah data prestasi belajar, data kemampuan representasi matematika dan data angket motivasi belajar matematika siswa. Berikut berturutturut disajikan deskripsi data dan grafik peningkatan rata-rata masing-masing variabel:

Tabel 4. Deskripsi Data Prestasi Belajar Siswa.

\begin{tabular}{ccccccc}
\hline & \multicolumn{2}{c}{$\boldsymbol{P B L}$} & \multicolumn{2}{c}{$\boldsymbol{I B L}$} & \multicolumn{2}{c}{ Konvensional } \\
\cline { 2 - 7 } & Pre & Post & Pre & Post & Pre & Post \\
\hline Rata- & 24,56 & 80 & 27,64 & 70,91 & 29,71 & 61,94 \\
rata & & & & 15,42 & 11,80 & 15,84 \\
SD & 9,53 & 11,39 & 13,62 & 15,42 & 52 & 92 \\
Max & 48 & 92 & 52 & 92 & 8 & 28 \\
Min & 8 & 32 & 8 & 24 & 8
\end{tabular}

Keterangan:

$\mathrm{n}=$ banyaknya siswa, $\mathrm{SD}=$ standar deviasi.

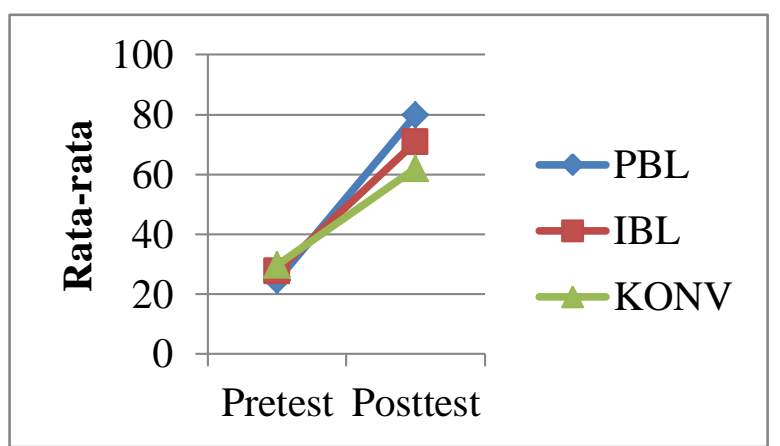

Gambar 1. Grafik Peningkatan Rata-rata Prestasi Belajar.

Berdasarkan hasil analisis statistik deskriptif pada Tabel 4 menunjukkan bahwa terdapat peningkatan skor rata-rata prestasi belajar sebelum perlakuan dengan sesudah perlakuan pada kelompok problem-based learning terdapat peningkatan sebesar 55,44, kelompok inquirybased learning, yaitu sebesar 43,27, sedangkan pada kelompok pembelajaran konvensional terdapat peningkatan sebesar 32,23. Berdasarkan Gambar 1 menunjukkan bahwa rata-rata prestasi belajar siswa yang mengikuti proses pembelajaran dengan PBL lebih baik dibandingkan dengan IBL dan pembelajaran konvensional. Adapun rata-rata prestasi belajar siswa yang mengikuti proses pembelajaran dengan IBL juga lebih baik dibandingkan dengan pembelajaran konvensional. 
Tabel 5. Deskripsi Data Kemampuan Representasi Matematika

\begin{tabular}{ccccccc}
\hline & \multicolumn{2}{c}{$\boldsymbol{P B L}$} & \multicolumn{2}{c}{$\boldsymbol{I B L}$} & \multicolumn{2}{c}{ Konvensional } \\
\cline { 2 - 7 } & Pre & Post & Pre & Post & Pre & Post \\
\hline Rata- & 7,92 & 34,19 & 7,94 & 29,76 & 9,69 & 25,11 \\
rata & 3,6 & 5,87 & 3,72 & 7,28 & 4,14 & 8,7 \\
SD & 3,40 & 20 & 39 & 18 & 39 \\
Max & 20 & 40 & 12 & 3 & 11 \\
Min & 3 & 19 & 3 & 12 \\
\hline
\end{tabular}

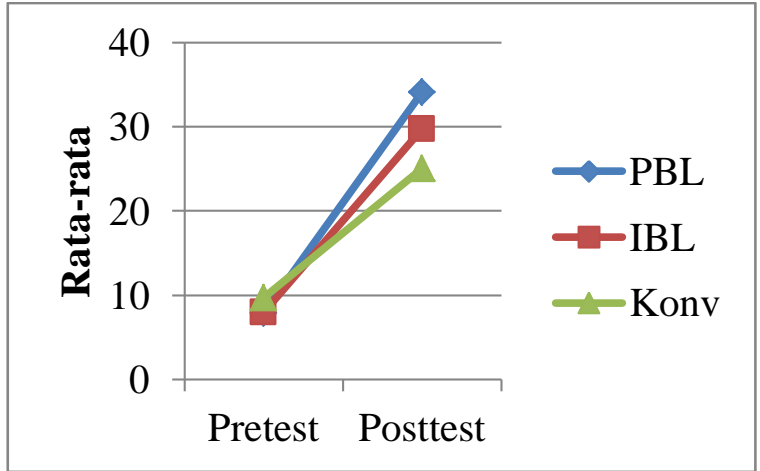

Gambar 2. Grafik Peningkatan Rata-rata Kemampuan Representasi Matematika

Berdasarkan hasil analisis statistik deskriptif pada Tabel 5 menunjukkan bahwa pada kelompok problem-based learning, terdapat peningkatan skor kemampuan representasi matematika sebelum perlakuan dengan setelah perlakuan yaitu sebesar 26,27, kelompok inquirybased learning terdapat peningkatan sebesar 21,82 , sedangkan kelompok pembelajaran konvensional terdapat 15,42. Berdasarkan Gambar 1 menunjukkan bahwa rata-rata kemampuan re- presentasi matematika siswa yang mengikuti proses pembelajaran dengan PBL lebih baik dibandingkan dengan IBL dan pembelajaran konvensional. Adapun rata-rata kemampuan representasi matematika siswa yang mengikuti proses pembelajaran dengan IBL juga lebih baik dibandingkan dengan konvensional.

Tabel 6. Distribusi Frekuensi Kemampuan Representasi Matematika Siswa

\begin{tabular}{ccccc}
\hline & & $\begin{array}{c}\text { Pre } \\
(\%)\end{array}$ & $\begin{array}{c}\text { Post } \\
(\%)\end{array}$ & $\begin{array}{c}\text { Peningkatan } \\
(\%)\end{array}$ \\
\hline \multirow{2}{*}{ PBL } & $\mathrm{T}$ & $0 \%$ & $72,22 \%$ & $72,22 \%$ \\
& $\mathrm{~S}$ & $2,78 \%$ & $27,78 \%$ & $25 \%$ \\
& $\mathrm{R}$ & $97,22 \%$ & $0 \%$ & \\
& $\mathrm{~T}$ & $0 \%$ & $39,39 \%$ & $39,39 \%$ \\
IBL & $\mathrm{S}$ & $3,03 \%$ & $54,55 \%$ & $51,52 \%$ \\
& $\mathrm{R}$ & $96,97 \%$ & $6,06 \%$ & \\
Kon & $\mathrm{T}$ & $0 \%$ & $25,71 \%$ & $25,71 \%$ \\
$\mathrm{~V}$ & $\mathrm{~S}$ & $11,43 \%$ & $48,57 \%$ & $37,14 \%$ \\
& $\mathrm{R}$ & $88,57 \%$ & $25,71 \%$ & \\
\hline
\end{tabular}

Ket: $\mathrm{T}=$ Tinggi, $\mathrm{S}=$ Sedang, $\mathrm{R}=$ Rendah.

Berdasarkan Tabel 6, dapat diketahui bahwa pada pretest dan posttest mengalami peningkatan kemampuan representasi matematika siswa pada masing-masing kelompok pada kategori tinggi dan sedang. Pada kelompok problembased learning mengalami peningkatan masingmasing sebesar $72,22 \%$ dan $25 \%$, pada kelompok inquiry-based learning masing-masing sebesar $39,39 \% \%$ dan $51,52 \%$, sedangkan pada kelompok pembelajaran konvensional masingmasing sebesar $25,71 \%$ dan $37,14 \%$.

Tabel 7. Deskripsi Data Motivasi Belajar Siswa

\begin{tabular}{ccccccc}
\hline & \multicolumn{2}{c}{$\boldsymbol{P B L}$} & \multicolumn{2}{c}{$\boldsymbol{I B L}$} & \multicolumn{2}{c}{ Konvensional } \\
\cline { 2 - 7 } & Pre & post & Pre & post & Pre & post \\
\hline Rata-rata & 89,47 & 121,33 & 91,21 & 111,79 & 88,31 & 101,94 \\
SD & 14,19 & 13,47 & 14,65 & 17,62 & 10,66 & 16,19 \\
Max & 115 & 139 & 115 & 139 & 105 & 132 \\
Min & 61 & 85 & 61 & 76 & 68 & 76 \\
\hline
\end{tabular}




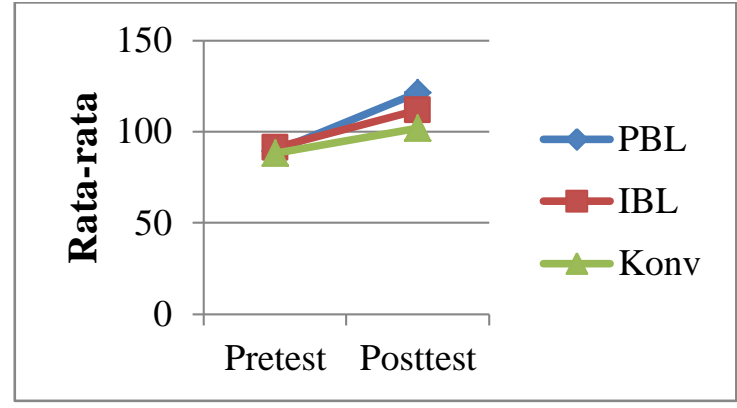

Gambar 3. Grafik Peningkatan Rata-rata Motivasi Belajar Matematika Siswa

Berdasarkan hasil analisis statistik deskriptif pada Tabel 7 menunjukkan bahwa pada kelompok problem-based learning, terdapat peningkatan skor motivasi belajar matematika siswa sebelum perlakuan dengan setelah perlakuan yaitu sebesar 31,86, pada kelompok inquiry-based learning terdapat peningkatan sebesar 20,58, sedangkan pada kelompok pembelajaran konvensional terdapat 13,63. Berdasarkan Gambar 3 menunjukkan bahwa rata-rata motivasi belajar siswa yang mengikuti proses pembelajaran dengan PBL lebih baik dibandingkan dengan IBL dan konvensional. Adapun rata-rata motivasi belajar siswa yang mengikuti proses pembelajaran dengan IBL juga lebih baik dibandingkan dengan konvensional.

Tabel 8. Distribusi Frekuensi Motivasi Belajar Matematika Siswa

\begin{tabular}{cccccc}
\hline \multirow{2}{*}{ Kel } & \multirow{2}{*}{ Kat } & \multicolumn{2}{c}{ Pre } & \multicolumn{2}{c}{ Post } \\
\cline { 3 - 6 } & & F & \% & F & \% \\
\hline \multirow{6}{*}{ PBL } & ST & 0 & 0 & 22 & 61,11 \\
& T & 8 & 22,22 & 10 & 27,78 \\
& S & 17 & 47,22 & 4 & 11,11 \\
& R & 11 & 30,56 & 0 & 0 \\
& SR & 0 & 0 & 0 & 0 \\
& ST & 0 & 0 & 12 & 36,36 \\
IBL & T & 9 & 27,27 & 12 & 36,36 \\
& S & 16 & 48,48 & 7 & 21,21 \\
& R & 8 & 24,24 & 2 & 6,06 \\
& SR & 0 & 0 & 0 & 0 \\
& ST & 0 & 0 & 6 & 17,14 \\
& Tonv & 5 & 14,29 & 16 & 45,71 \\
& S & 17 & 48,57 & 8 & 22,86 \\
& R & 13 & 37,14 & 5 & 14,29 \\
& SR & 0 & 0 & 0 & 0 \\
\hline
\end{tabular}

Berdasarkan Tabel 8, dapat diketahui bahwa pada kelompok problem-based learning setelah perlakuan secara kumulatif $88,89 \%$ siswa memiliki kategori motivasi belajar matematika yang tinggi dan sangat tinggi, sedangkan sebelum perlakuan secara kumulatif hanya 22,22 \%, sehingga dapat dikatakan terdapat peningkatan motivasi belajar matematika siswa sebesar
66,67\%. Pada kelompok inquiry-based learning sebesar $72,72 \%$ siswa yang memiliki kriteria motivasi belajar matematika yang tinggi dan sangat tinggi, sedangkan sebelum perlakuan secara kumulatif hanya $27,27 \%$ siswa, sehingga dapat dikatakan terdapat peningkatan motivasi belajar matematika siswa sebesar 45,45\%. Pada kelompok pembelajaran konvensional sebesar $62,85 \%$ siswa yang memiliki kriteria motivasi belajar matematika yang tinggi dan sangat tinggi, sedangkan sebelum perlakuan secara kumulatif sebesar $14,29 \%$ siswa, sehingga dapat dikatakan terdapat peningkatan motivasi belajar matematika siswa sebesar $48,60 \%$.

Data penelitian ini selanjutnya dianalisis untuk mengetahui keefektifan dari masing-masing kelompok pembelajaran terhadap prestasi belajar, kemampuan representasi matematika dan motivasi belajar siswa. Analisis keefektifan ini digunakan uji one sample t test. Sedangkan untuk mengetahui perbandingan keefektifan dari masing-masing kelompok belajar akan dilakukan uji univariat dengan kriteria Bonferroni pada taraf signikansi 5\%. Sebelum dilakukan uji one sample $t$ test dan uji univariat dengan kriteria Bonferroni maka terlebih dahulu dilakukan Uji MANOVA dengan melihat nilai signifkasi pada Wilks' Lambda maka pemenuhan asumsiasumsi multivariat perlu dilakukan. Berikut hasil analisis pemenuhan asumsi normalitas dan homogenitas multivariat baik sebelum maupun sesudah perlakuan ditunjukkan pada Tabel 9 dan Tabel 9 di bawah ini.

Tabel 9. Hasil Uji Normalitas Multivariat

\begin{tabular}{ccc}
\hline \multirow{2}{*}{ Kelas } & \multicolumn{2}{c}{$d_{i}^{2}$} \\
\cline { 2 - 3 } & Pre & Post \\
\hline PBL & $47,22 \%$ & $58,33 \%$ \\
IBL & $48,48 \%$ & $51,52 \%$ \\
Konv & $42,86 \%$ & $45,71 \%$ \\
\hline
\end{tabular}

Tabel 10. Hasil uji Box's $M$

\begin{tabular}{ccc}
\hline & Pre & Post \\
\hline Box's $M$ & 14,898 & 13,846 \\
F & 1,188 & 1,104 \\
Sig. & 0,285 & 0,351 \\
\hline
\end{tabular}

Hasil analisis menunjukkan bahwa semua data baik tes awal maupun tes akhir berdistribusi normal dan kelompok-kelompok data terkait uji MANOVA memiliki matriks-kovarians yang sama. Karena kedua asumsi terpenuhi maka uji MANOVA dan Uji univariat dapat dilakukan.

Selanjutnya dilakukan uji MANOVA untuk mengetahui perbedaan mean masing-masing kelompok baik sebelum maupun sesudah perla- 
kuan dengan melihat kriteria Wilks' Lambda. Berikut data hasil uji MANOVA baik sebelum maupun sesudah perlakuan yang ditunjukkan pada Tabel 11 berikut.

Tabel 11. Uji MANOVA (Wilks' Lambda)

\begin{tabular}{ccc}
\hline & Pre & Post \\
\hline Value & 0.929 & 0.754 \\
F & 1.238 & 4.993 \\
Sig. & 0.288 & 0.00 \\
\hline
\end{tabular}

Berdasarkan hasil uji MANOVA sebelum perlakuan menunjukkan angka signikasi lebih besar dari $0,05(0,288>0,05)$ maka hal ini menunjukkan bahwa ketiga kelompok belajar memiliki mean kelompok yang sama artinya sebelum penelitian dilakukan peneliti telah memastikan bahwa ketiga kelompok berasal dari mean yang sama secara multivariat $\left(\mathrm{H}_{0}\right.$ ditolak atau tidak terdapat perbedaan mean antara kelompok belajar problem-based learning, inquiry-based learning dan pembelajaran konvensional). Sedangkan hasil uji MANOVA setelah perlakuan menunjukkan bahwa angka signikansi yang lebih kecil dari $0,05(0,00<0,05)$ maka hal ini menunjukkan bahwa setelah perlakuan ketiga kelompok terdapat perbedaan mean multivariat $\left(\mathrm{H}_{0}\right.$ diterima atau terdapat perbedaan mean antara kelompok belajar problembased learning, inquiry-based learning dan pembelajaran konvensional) artinya bahwa setelah diberikan perlakuan ketiga kelompok tersebut menunjukkan adanya perbedaan, perbedaan yang dimaksud adalah keefektifan dari masingmasing kelompok belajar terhadap prestasi belajar, kemampuan representasi matematika dan motivasi belajar matematika siswa serta membandingkan kelompok belajar mana yang lebih efektif ditinjau dari prestasi belajar, kemampuan representasi matematika dan motivasi belajar matematika siswa. Untuk mengetahui keefektifan masing-masing kelompok belajar maka akan dilakukan uji one sample t test sedangkan untuk mengetahui perbandingan keefektifan dari masing-masing kelompok belajar terhadap prestasi belajar, kemampuan representasi matematika dan motivasi belajar siswa maka dilakukan uji Bonferroni. Adapun hasil uji one sample t test dan uji Bonferroni akan disajikan berturut-turut dalam Tabel 12 dan Tabel 13 di berikut ini:

Tabel 12. Uji Keefektifan

\begin{tabular}{clcccc}
\hline Kel & \multicolumn{1}{c}{ Variabel } & $\overline{\boldsymbol{x}}$ & $\boldsymbol{d f}$ & $\boldsymbol{t}_{\text {hitg }}$ & $\boldsymbol{t}_{\text {tab }}$ \\
\hline \multirow{3}{*}{$P B L$} & Prestasi & 80,00 & 36 & 7,790 & 2.030 \\
& Kemampuan Representasi Matematika & 34,19 & 36 & 8,255 & 2,030 \\
& Motivasi & 121,33 & 36 & 11,562 & 2,030 \\
\multirow{3}{*}{ IBL } & Prestasi & 70,91 & 33 & 2,167 & 2,037 \\
& Kemampuan Representasi Matematika & 29,76 & 33 & 2,921 & 2,037 \\
& Motivasi & 117,79 & 33 & 5,390 & 2,037 \\
& Prestasi & 61,94 & 35 & 1,125 & 2,032 \\
Konv & Kemampuan Representasi Matematika & 25,11 & 35 & 0,593 & 2,032 \\
& Motivasi & 101,94 & 35 & 2,501 & 2,032 \\
\hline
\end{tabular}

Berdasarkan Tabel 12 diketahui bahwa problem-based learning dan inquiry-based learning ditinjau dari prestasi belajar, kemampuan representasi matematika dan motivasi belajar siswa masing-masing memiliki nilai $t_{\text {hitung }}$ sebesar 7,790 dan 2,167 untuk prestasi, 8,255 dan 2,921 untuk kemampuan representasi matematika dan motivasi belajar siswa sebesar 11,562 dan 5,390, ketiganya lebih besar dari $\mathrm{t}_{\text {tabel }}$, sehingga dapat disimpulkan bahwa problem-based learning dan inquiry-based learning efektif ditinjau dari prestasi belajar, kemampuan representasi matematika dan motivasi belajar siswa. Sedangkan pembelajaran konvensional memiliki nilai $t_{\text {hitung }} 1,125$ untuk prestasi dan 0,593 untuk kemampuan representasi matematika, keduanya lebih kecil dari $t_{\text {tabel }}$ yaitu 2,032, sedangkan nilai $t_{\text {hitung }}$ untuk motivasi sebesar
2,501 lebih besar dari $t_{\text {tabel }}$ yaitu 2,032, sehingga dapat disimpulkan bahwa pembelajaran konvensional tidak efektif ditinjau dari prestasi belajar dan kemampuan representasi matematika dan efektif pada motivasi belajar siswa.

Tabel 13. Uji Perbedaan Keefektifan

\begin{tabular}{clc}
\hline $\begin{array}{c}\text { Perbandingan } \\
\text { Kel }\end{array}$ & \multicolumn{1}{c}{ Variabel } & Sig \\
\hline PBL dengan & Prestasi Belajar & 0,00 \\
Konv & $\begin{array}{l}\text { Kemampuan representasi } \\
\text { matematika }\end{array}$ & 0,00 \\
& Motivasi Belajar & 0,00 \\
IBL dengan & Prestasi Belajar & 0,037 \\
Konv & KRM & 0,036 \\
& Motivasi Belajar & 0,039 \\
PBL dengan $I B L$ & Prestasi Belajar & 0,032 \\
& KRM & 0,046 \\
& Motivasi Belajar & 0,045 \\
\hline
\end{tabular}


Berdasarkan Tabel 13 menunjukkan bahwa pada masing-masing perbandingan kelompok antara $P B L$ dengan Konv, $I B L$ dengan Konv dan $P B L$ dengan $I B L$ ditinjau dari prestasi belajar, kemampuan representasi matematika dan motivasi belajar siswa angka signifikansinya masing-masing lebih besar dari 0,05 sehingga $\mathrm{H}_{0}$ ditolak. Dengan demikian dapat disimpulkan bahwa: (1) terdapat perbedaan antara problembased learning dibandingkan dengan pembelajaran konvensional, (2) terdapat perbedaan antara inquiry-based learning dibandingkan dengan pembelajaran konvensional, (3) problembased learning lebih efektif dibandingkan dengan inquiry-based learning ditinjau dari prestasi belajar, kemampuan representasi matematika dan motivasi belajar siswa.

\section{Pembahasan}

Upaya pembangunan kualitas sumber daya manusia indonesia terus dilakukan mela-lui berbagai institusi pendidikan dengan cara menerapkan berbagai inovasi-inovasi yang baru, baik inovasi dalam hal teknologi maupun inovasi dalam hal pembelajaran. Sesuai dengan harapan dari peraturan pemerintah terkait tentang pendidikan, inovasi dalam bidang pembelajaran termasuk dalam pembelajaran matematika di sekolah menengah memang sangat dibutuhkan. Inovasi dalam proses belajar mengajar salah satunya adalah inovasi yang bisa dilakukan oleh guru dalam penerapan berbagai jenis inovasi dalam pembelajaran. Mengingat pentingnya prestasi belajar, kemampuan representasi matematika dan motivasi belajar siswa maka diperlukan suatu inovasi dalam pembelajaran yang efektif terhadap ketiga aspek tersebut, sehingga sumber daya manusia Indonesia dapat meningkatkan dan mampu menghadapi segala bentuk perubahan dan perkembangan dalam era globalisasi.

Problem-based learning dan inquirybased learning merupakan pembelajaran yang sama-sama efektif dikarenakan kedua pembelajaran tersebut memiliki karakteristik yang mampu membantu siswa meningkatkan kemampuan siswa, baik karakteristik yang diungkapkan oleh Arends (2008, p.42) maupun oleh Tan (2004, p.8). Karakteristik tersebut dian-taranya (1) masalah autentik atau (real-world) adalah sebagai titik awal pembelajaran yang mampu membangkitkan motivasi siswa, dengan kata lain siswa akan merasa tertantang untuk menggunakan kompetensi yang mereka miliki untuk memecahkan masalah tersebut, (2) dalam menyelesaikan masalah siswa dituntut menggunakan berbagai sumber pengetahuan dan informasi, (3) siswa fokus melakukan diskusi dan investigasi untuk menyelesaikan masalah dalam kelompoknya sehingga akan terbiasa collaborative, communicative, dan cooperative dalam menyelesaikan masalah sehari-hari, dan (4) dalam proses PBL menuntun siswa untuk melakukan evaluasi penyelesaian masalah dengan memeriksa kembali solusi yang didapatkan atau membandingkan dengan pekerjaan teman lainnya.

Coffman (2009, p.1) menyebutkan bahwa pembelajaran dengan inquiry merupakan kegiatan pembelajatan yang akan melibatkan secara maksimal seluruh kemampuan siswa untuk mencari dan menyelidiki sesuatu secara sistematis, kritis, logis dan analitis sehingga siswa dapat merumuskan sendiri penemuannya dengan penuh percaya diri.

Berdasarkan hasil analisis deskriptif pada Tabel 4, Tabel 5 dan Tabel 7 sesudah perlakuan (posttest) menunjukkan nilai rata-rata dari kelompok problem-based learning dan inquirybased learning lebih tinggi dibandingkan dengan dengan kelompok pembelajaran konvensional. Pada Gambar 1, Gambar 2 dan Gambar 3 menunjukkan juga bahwa nilai rata-rata dari kelompok problem-based learning dan inquirybased learning lebih tinggi dibandingkan dengan dengan kelompok pembelajaran konvensional.

Analisis juga dilakukan dengan uji one sample $t$ test menunjukkan bahwa problembased learning dan inquiry-based learning efektif ditinjau dari prestasi belajar, kemampuan representasi matematika dan motivasi belajar siswa. Sedangkan pada kelompok pembelajaran konvensional efektif pada motivasi belajar siswa, hal ini ditunjukkan pada Tabel 12. Jika ditinjau berdasarkan nilai rata-rata $(\bar{x})$ yang diperoleh ketiga pembelajaran berdasarkan ketiga aspek tersebut maka berdasarkan Tabel 12, problem-based learning dan inquiry-based learning menunjukkan nilai rata-rata yang lebih tinggi dibandingkan pembelajaran konvensional atau dengan kata lain bahwa problem-based learning dan inquiry-based learning lebih efektif dibandingkan dengan pembelajaran konvensional terhadap prestasi belajar, kemampuan representasi matematika dan motivasi belajar siswa.

Hasil analisis lanjut dilakukan juga untuk mengetahui perbandingan keefektifan dari ketiga kelompok pembelajaran tersebut. Berdasar- 
kan Tabel 13 menunjukkan bahwa terdapat perbedaan keefektifan antara problem-based learning dan inquiry-based learning dibandingkan dengan pembelajaran konvensional. Selain itu juga problem-based learning lebih efektif dibandingkan dengan inquiry-based learning ditinjau dari prestasi belajar, kemampuan representasi matematika dan motivasi belajar siswa.

\section{SIMPULAN DAN SARAN}

\section{Simpulan}

Berdasarkan pengujian hipotesis diperoleh kesimpulan bahwa pembelajaran problembased learning dan inquiry-based learning lebih efektif untuk meningkatkan prestasi belajar, kemampuan representasi matematika dan motivasi belajar siswa. Secara lebih rinci, diperoleh kesimpulan sebagai berikut: (1) Problem-based learning efektif ditinjau dari prestasi belajar, kemampuan representasi matematika dan motivasi belajar siswa, (2) Inquiry-based learning efektif ditinjau dari prestasi belajar, kemampuan representasi matematika dan motivasi belajar siswa, (3) Pembelajaran konvensional efektif ditinjau dari motivasi belajar siswa, (4) Problem-based learning dan inquiry-based learning lebih efektif dibandingkan dengan pembelajaran konvensional ditinjau dari aspek prestasi belajar, kemampuan representasi matematika dan motivasi belajar siswa, (5) Problem-based learning lebih efektif dibandingkan dengan inquiry-based learning ditinjau dari aspek prestasi belajar, kemampuan representasi matematika dan motivasi belajar siswa.

\section{Saran}

Berdasarkan hasil dan temuan yang diperoleh dalam penelitian ini serta dengan memperhatikan keterbatasan penelitian yang telah disinggung, saran yang dapat disampaikan adalah sebagai berikut: (1) Disarankan kepada dinas pendidikan atau kepala sekolah untuk mengadakan pelatihan-pelatihan kepada guru matematika untuk menguasai dan mengembangkan pembelajaran dengan problem-based learning dan inquiry-based learning, dengan harapan dapat meningkatkan efektivitas pembelajaran matematika sehingga dapat berpengaruh positif terhadap proses belajar siswa, (2) Disarankan kepada guru untuk menggunakan dan menerapkan inovasi-inovasi baru dalam pembelajaran matematika dengan menerapkan problem-based learning dan inquiry-based learning dalam pembelajaran matematika, (3) Disarankan kepada peneliti yang berminat untuk menerapkan kedua pembelajaran tersebut pada materi yang lain sehingga dapat memberikan bukti yang lebih kuat mengenai keefefktifan kedua pembelajaran tersebut.

\section{DAFTAR PUSTAKA}

Arends, R., I. (2008). Learning to teach. (Terjemahan Helly Prajitno Soetjipto \& Sri Mulyantini Soetjipto). New York: McGraw Hill Companies. (Buku Asli Diterbitkan tahun 2007).)

Arends, R., I., \& Kilcher, A. (2010). Teaching for student learning. New York: Routledge.

Azwar, S. (2011). Tes prestasi: fungsi dan pengembangan pengukuran prestasi belajar. Yogyakarta: Pustaka Pelajar.

Baden, M., S., \& Major, C., H. (2004). Foundations of problem-based learning. New York: Society for Research into Higher Education \& Open University Press.

Beetlestone, F. (2012). Creative learning. (diterjemahkan oleh Narulita Yusron). Philadelphia: Open University Press. (Buku Asli diterbitkan tahun 1998).

Coffman, T. (2009). Engaging students through inquiry-oriented learning and technology. Lanham: The Rowman \& Littlefield Publishing Group, Inc.

Depdiknas. (2006). Peraturan menteri Nomor 22 tahun 2006, tentang Standar Pendidikan Nasional.

Duch, B., J., Groh, S., E., \& Allen, D., E. (2001). The power of problem-based learning. Sterling, Virginia: Stylus.

Harian Kompas 2 Juni 2012 "Banyak siswa tak lulus ujian matematika. kompas edukasi. Di akses di http://edukasi.kompas.com

Hwang, W., Y., et al. (2007). Multiple representation skills and creativity effects on mathematical problem solving using a multimedia whiteboard system. Educational Technology And Society. Vol 10 no 2, pp 191-212.

Jacobsen, D., A., Eggen, P., \& Kauchak, D. (2009). Methods for teaching. (diterjemahkan oleh Achmad Fawaid \& Khoirul 
Anam). New Jersey: Pearson Education, Inc. (Buku Asli Diterbitkan tahun 2009).

Masykur, Ag., M., \& Fathani, A., H. (2008). Mathematical intelligence. Yogyakarta: Ar-Ruzz Media.

Moore, K. D. (2009). Effective instructional strategies: From theory to practice $\left(2^{\text {nd. }} . e d\right)$. Thousand Oaks, CA: SAGE Publications, Inc..

Mudjiman, H. (2007). Belajar mandiri (selfmotovated learning). Surakarta: Lembaga Pengembangan Pendidikan (LPP) \& UPT Penerbitan dan Percetakan UNS (UNS Press).

Muijs, D., \& Reynolds, D. (2008). Efective teaching. (Terjemah Helly Prajitno Soetjipto \& Sri Mulyantini Soetjipto). London: Sage Publication Ltd. (Buku Asli Diterbitkan tahun 2008).

NCTM. (2000). Principles and standards for school mathematics. Reton, VA: NCTM, Inc.

Santrock, J., W. (2009). Psikologi pendidikan (Penerjemah Diana Angelica). New York: McGraw-Hill. (Buku Asli Diterbitkan Tahun 2008).

Santrock, J., W. (2011). Educational psychology. New York: McGraw-Hill.

Sobel, M. A., \& Maletsky, E. M. (2004). Mengajar matematika, sebuah buku sumber alat peraga, aktivitas dan strategi. (Terjemahan Suyono). Needham Height, MA: Allyn \& Balcon. (Buku asli diterbitkan tahun 1999).
Sudijono, A. (2008). Pengantar statistika pendidikan. Jakarta: PT. Raja Grafindo Persada.

Tan, O., S. (2004). Enhancing thinking through problem-based learning approaches. Bangkok: Cengage Learning.

Taylor, J., H., \& Bilbrey, J., K., Jr. (2011). Teacher perceptions of inquiry-based instruction vs teacher-based instruction. International Review of Social Sciences and Humanities. Vol.2, No.1, pp. 152162.

Uno, H., B. (2011). Teori motivasi dan pengukurannya. Jakarta: PT Bumi Aksara.

Venkat, H., \& Assien, A., A. (2011). Mathematics in a globalized world. Proceedings of the seventeenth national congress of the association for mathematics education of south Africa (AMESA). Volume 1. Published AMESA.

Wardhani, S., \& Rumiati (2011). Instrumen penilaian hasil belajar matematika smp: belajar dari pisa dan timss. Yogyakarta: PPPPTK Matematika.

White, J., H., D., C., \& Harbaugh, A., P. (2010). Learner-centered instruction. Thousand Oaks, California: Sage.

Wolkfolk, A. (2007). Educational psychology $\left(10^{r d} e d\right)$. Boston: Pearson Education.

Yunus, A., S., MD \& Ali, W., Z., W. (2009). Motivation in the learning of mathematics. European Journal of Social Science, 7, 93-101. 